\title{
PROBABILITY DENSITY FUNCTIONS FOR DESCRIPTION OF DIAMETER DISTRIBUTION IN THINNED STANDS OF Tectona grandis
}

\author{
Daniel Henrique Breda Binoti ${ }^{1}$, Mayra Luiza Marques da Silva Binoti², Helio Garcia Leite ${ }^{3}$, \\ Leonardo Fardin ${ }^{4}$, Julianne de Castro Oliveira ${ }^{5}$
}

(received: October 20, 2010; accepted: December 22, 2011)

\begin{abstract}
The objective of this study was to evaluate the effectiveness of fatigue life, Frechet, Gamma, Generalized Gamma, Generalized Logistic, Log-logistic, Nakagami, Beta, Burr, Dagum, Weibull and Hyperbolic distributions in describing diameter distribution in teak stands subjected to thinning at different ages. Data used in this study originated from 238 rectangular permanent plots $490 \mathrm{~m}^{2}$ in size, installed in stands of Tectona grandis L. f. in Mato Grosso state, Brazil. The plots were measured at ages 34 , $43,55,68,81,82,92,104,105,120,134$ and 145 months on average. Thinning was done in two occasions: the first was systematic at age 81 months, with a basal area intensity of $36 \%$, while the second was selective at age 104 months on average and removed poorer trees, reducing basal area by $30 \%$. Fittings were assessed by the Kolmogorov-Smirnov goodness-of-fit test. The Log-logistic (3P), Burr (3P), Hyperbolic (3P), Burr (4P), Weibull (3P), Hyperbolic (2P), Fatigue Life (3P) and Nakagami functions provided more satisfactory values for the k-s test than the more commonly used Weibull function.
\end{abstract}

Key words: Teak, Weibull Distribution, thinning.

\section{FUNÇÕES DENSIDADE DE PROBABILIDADE PARA DESCRIÇÃO DA DISTRIBUIÇÃO DIAMÉTRICA DE POVOAMENTOS DESBASTADOS DE Tectona grandis}

RESUMO: Objetivou-se, neste trabalho, avaliar a eficiência das distribuições fatigue life, Frechet, gama, gama generalizada, logística generalizada, log-logística, Nakagami, beta, Burr, Dagum, Weibull e hiperbólica, para a descrição da distribuição diamétrica de povoamentos de teca submetidos a desbaste em diferentes idades. Os dados utilizados neste estudo foram provenientes de 238 parcelas permanentes retangulares de $490 \mathrm{~m}^{2}$ de área, instaladas em povoamentos de Tectona grandis L. $f$. no Estado do Mato Grosso, Brasil. As parcelas foram mensuradas, aos 34, 43, 55, 68, 81, 82, 92, 104, 105, 120,134 e 145 meses em média. O povoamento foi desbastado em duas ocasiões, sendo o primeiro sistemático e aos 81 meses, com intensidade de $36 \%$ de área basal, e o segundo seletivo, removendo as piores árvores, aos 104 meses, em média, com redução de 30\% de área basal. Os ajustes foram avaliados pelo teste de aderência Kolmogorov-Smirnorv. As funções Log-Logística (3P), Burr (3P), hiperbólica (3P), Burr (4P), Weibull (3P), Hyperbólica (2P), Fatigue Life (3P) e Nakagami, apresentaram valores para o teste $k$-s mais satisfatórios que a função comumente usada (Weibull).

Palavras-chave: Teca, Distribuição Weibull, desbaste.

\section{INTRODUCTION}

Wood from Tectona grandis L. f. ranks high in the global market, particularly for the main intended purpose of furniture making, it being necessary to adopt thinning procedures in order to boost tree diameter for multiple product applications, along with artificial pruning in order to obtain better quality wood in the final cutting process (LEITE et al., 2006).
Making projections of diameter distribution is critical for the management of forests intended for multiple products, enabling a more accurate economic analysis (CLUTTER et al., 1983). Projection could be done by using models that estimate diameter distribution based on a current distribution or based on the characteristics of the stand, enabling to simulate thinning procedures and to quantify multiple wood products (CLUTTER et al., 1983; KNOBELL, 1986; NOGUEIRA et al., 2005; SIIPILEHTO, 2007).

${ }^{1}$ Forest Engineer, D.Sc. candidate in Forest Science - Departamento de Engenharia Florestal - Universidade Federal de Viçosa - 36570-000 - Viçosa, MG, Brasil - daniel.binoti@ufv.br

${ }^{2}$ Forest Engineer, Professor, D.Sc. candidate in Forest Science - Departamento de Engenharia Florestal - Universidade Federal de Viçosa - 36570-000 Viçosa, MG, Brasil - mayra.silva@ufv.br

${ }_{3}^{3}$ Forest Engineer, Professor, D.Sc. in Forest Science - Departamento de Engenharia Florestal - Universidade Federal de Viçosa - 36570-000 - Viçosa, MG,Brasil-hgleite@gmail.com

${ }^{4}$ Forest Engineer - Floresteca - Av. Gov. João Ponce de Arruda, 1054 - 78110-375 - Várzea Grande, MT, Brasil - leonardo.fardin@floresteca.com.br ${ }^{5}$ Forest Engineer, M.Sc. candidate in Forest Science - Departamento de Engenharia Florestal - Universidade Federal de Viçosa - 36570-000 - Viçosa, MG, Brasil-juliannecoliveira@gmail.com

Cerne, Lavras, v. 18, n. 2, p. 185-196, abr./jun. 2012 
A common characteristic in this type of modeling is the presence of a probability density function (pdf).

Different types of statistical distribution have already been used to describe diameter structure in forest stands, including: Gamma (NELSON, 1964), log-normal (BLISS; REINKER, 1965), Beta (CLUTTER; BENNETT, 1965; PALAHÍ et al., 2007), Johnson's SB (HAFLEY; SCHUREUDER, 1977; PALAHÍ et al., 2007), Hyper (LEITE et al., 2009) and the Weibull distribution (BAILEY; DELL, 1973; PALAHÍ et al., 2007; WEIBULL, 1951). Since 1973, based on the study proposed by Bailey and Dell (1973), the Weibull function (MURTHY et al., 2004) has been widely used in forestry (CAMPOS; TURNBULL, 1981; CAO, 2004; CLUTTER; ALLISON, 1974; HAFLEY; SCHREUDER, 1977; KNOWE et al., 1997; MATNEY; SULLIVAN, 1982; NOGUEIRA et al., 2005; PALAHÍ et al., 2006, 2007).

A pdf may be fitted by methods of moments (FRAZIER, 1981), percentiles (BAILEY et al., 1989), maximum likelihood (FISHER, 1922), by combining methods of moments and percentiles (BALDWIN JUNIOR; FEDUCCIA, 1987), or by heuristic methods (ABBASI et al., 2006, 2008).

Despite the prevalence of the Weibull pdf, statistical studies have presented new functions with differing characteristics, flexibility and fitting capability. Depending on the type of stand and horizontal structure found, other functions might result in greater accuracy. Therefore, this study aimed to assess the effectiveness of Fatigue life, Frechet, Gamma, Generalized Gamma, Generalized Logistic, Log-logistic, Nakagami, Beta, Burr, Dagum, Weibull and Hyperbolic distributions in describing diameter distribution in teak stands subjected to thinning at different ages.

\section{MATERIAL AND METHODS}

\subsection{Data description}

Data used in this study originated from 238 rectangular permanent plots $490 \mathrm{~m}^{2}$ in area, installed in stands of Tectona grandis L. f. in Mato Grosso State, Brazil. These stands were located in a lowland region with geographical coordinates $15^{\circ} 02^{\prime}$ to $15^{\circ} 11^{\prime}$ south latitude and $56^{\circ} 29^{\prime}$ to $56^{\circ} 35^{\prime}$ 'west longitude, with initial spacing of $3.0 \times 2.0 \mathrm{~m}$. The average annual precipitation in the region is 1,300 to $1,600 \mathrm{~mm}$, with six dry months, and the average annual temperature is $25.3{ }^{\circ} \mathrm{C}$.

The plots were measured at ages $34,43,55,68,81$, $82,92,104,105,120,134$ and 145 months on average. In each plot and on each occasion, the diameter of all trees was measured $1.30 \mathrm{~m}$ above the ground (dbh). The stand was thinned on two occasions, the first thinning was systematic at 81 months, with a basal area intensity of $36 \%$, while the second was selective at 104 months and removed the poorer trees, reducing the basal area by $30 \%$ on average.

\subsection{Probability Density Functions}

For each plot and each measurement occasion, the following functions were fitted:

- Beta (KRISHNAMOORTHY, 2006)

$$
f(x)=\frac{1}{B\left(\alpha_{1}, \alpha_{2}\right)} \frac{(x-a)^{\alpha_{1}-1}(b-x)^{\alpha_{2}-1}}{(b-a)^{\alpha_{1}+\alpha_{2}-1}}
$$

where

$B\left(\alpha_{1}, \alpha_{2}\right)=\int_{0}^{1} t^{\alpha_{1}-1}(1-t)^{\alpha_{2}-1} d t \quad\left(\alpha_{1}, \alpha_{2}>0\right)$,

$\alpha_{1}$ and $\alpha_{2}$ are shape parameters $\left(\alpha_{1}, \alpha_{2}>0\right), a, b$ are the limits of the distribution $(a<b)$

- Fatigue Life (Birnbaum-Saunders) (JOHNSON et al., 1995)

$f(x)=\frac{\sqrt{\frac{(x-\gamma)}{\beta}}+\sqrt{\frac{\beta}{(x-\gamma)}}}{2 \alpha(x-\gamma)} \phi\left(\frac{1}{\alpha}\left(\sqrt{\frac{(x-\gamma)}{\beta}}-\sqrt{\frac{\beta}{(x-\gamma)}}\right)\right)$

where

$\Phi(x)=\frac{1}{\sqrt{2 \pi}} \int e^{-\frac{t^{2}}{2}} d t$

$\phi(x)=\frac{e^{\frac{-x^{2}}{2}}}{\sqrt{2 \pi}}$,

$\alpha$ is the shape parameter $(\alpha>0), \beta$ is the scale parameter $(\beta>0), \gamma$ is the location parameter $(\gamma \equiv 0$, for a distribution with one parameter).

- Frechet (BURY, 1999)

$f(x)=\frac{\alpha}{\beta}\left(\frac{\beta}{x-\gamma}\right)^{\alpha+1} e^{\left(-\left(\frac{\beta}{x-\gamma}\right)^{\alpha}\right)}$

where

$\alpha$ is the shape parameter $(\alpha>0), \beta$ is the scale parameter $(\beta>0), \gamma$ is the location parameter $(\gamma \equiv 0$, for a distribution with two parameters).

Cerne, Lavras, v. 18, n. 2, p. 185-196, abr./jun. 2012 
- Gamma (KRISHNAMOORTHY, 2006)

$f(x)=\frac{(x-\gamma)^{\alpha-1}}{\beta^{\alpha} \Gamma(\alpha)} e\left(-\left(\frac{x-\gamma}{\beta}\right)\right)$

where

$\Gamma(\alpha)=\int_{0}^{\infty} t^{\alpha-1} e^{-t} d t \quad(\alpha>0)$

$\alpha$ is the shape parameter $(\alpha>0), \beta$ is the scale parameter $(\beta>0), \gamma$ is the location parameter $(\gamma \equiv 0$, for a distribution with two parameters)

- Generalized Logistic (JOHNSON et al., 1995)

$$
f(x)= \begin{cases}\frac{(1+a z)^{-1-\frac{1}{k}}}{\beta\left(1+(1+a z)^{-\frac{1}{\alpha}}\right)^{2}} & \alpha \neq 0 \\ \frac{e^{(-z)}}{\beta\left(1+e^{-z}\right)^{2}} & \alpha=0\end{cases}
$$

where

$z=\frac{x-y}{\beta}$

$\alpha$ is the shape parameter $(\alpha>0), \beta$ is the scale parameter $(\beta>0), \gamma$ is the location parameter $(\gamma \equiv 0$, for a distribution with two parameters)

- Log-Logistic (JOHNSON et al., 1995)

$f(x)=\frac{\alpha}{\beta}\left(\frac{x-\gamma}{\beta}\right)^{\alpha-1}\left(1+\left(\frac{x-\gamma}{\beta}\right)^{\alpha}\right)^{-2}$

where

$\alpha$ is the shape parameter $(\alpha>0), \beta$ is the scale parameter $(\beta>0), \gamma$ is the location parameter $(\gamma \equiv 0$, for a distribution with two parameters)

- Weibull (MURTHY et al., 2004)

$f(x)=\frac{\gamma}{\beta}\left(\frac{x-\alpha}{\beta}\right)^{\gamma-1} e^{\left(-\left(\frac{x-\alpha}{\beta}\right)^{\gamma}\right)}$

where

$\gamma$ is the shape parameter $(\gamma>0), \beta$ is the scale parameter $(\beta>0), \alpha$ is the location parameter $(\alpha \equiv 0$, for a distribution with two parameters)
- Burr (JOHNSON et al., 1995)

$f(x)=\frac{\alpha k\left(\frac{x-\gamma}{\beta}\right)^{\alpha-1}}{\beta\left(1+\left(\frac{x-\gamma}{\beta}\right)^{\alpha}\right)^{k+1}}$

where

$\alpha$ and $k$ are shape parameters $(\alpha>0), \beta$ is the scale parameter $(\beta>0), \gamma$ is the location parameter $(\gamma \equiv 0$, for a distribution with two parameters)

- Generalized Gamma (JOHNSON et al., 1995)

$f(x)=\frac{k(x-y)^{k \alpha-1}}{\beta^{k \alpha} \Gamma(\alpha)} \exp \left(-((x-y) / \beta)^{k}\right)$

where

$\alpha$ and $k$ are shape parameters $(\alpha>0), \beta$ is the scale parameter $(\beta>0), \gamma$ is the location parameter $(\gamma \equiv 0$, for a distribution with two parameters)

- Nakagami (LAURENSON, 1994)

$f(x)=\frac{2 m^{m}}{\Gamma(m) \Omega^{m}} x^{2 m-1} \exp \left(-\frac{m}{\Omega} x^{2}\right)$

where

$\mathrm{m}$ and $\Omega$ are constant parameters ( $\mathrm{m} \geq 0.5$ and $\Omega>0$ )

- Dagum (KLEIBER; KOTZ, 2003)

$$
f(x)=\frac{\alpha k\left(\frac{x-\gamma}{\beta}\right)^{\alpha k-1}}{\beta\left(1+\left(\frac{x-\gamma}{\beta}\right)^{\alpha}\right)^{k+1}}
$$

where

$\alpha$ and $k$ are shape parameters $(\alpha>0), \beta$ is the scale parameter $(\beta>0), \gamma$ is the location parameter $(\gamma \equiv 0$, for a distribution with two parameters)

- Hyperbolic (GUIMARÃES, 2002)

$f(x)=\frac{\alpha}{\beta}\left(\frac{x-\gamma}{\beta}\right)^{(\alpha-1)}\left(1-\tanh \left(\left(\frac{x-\gamma}{\beta}\right)^{\alpha}\right)^{2}\right)$

where

$\alpha$ is the shape parameter $(\alpha>0), \beta$ is the scale parameter $(\beta>0), \gamma$ is the location parameter $(\gamma \equiv 0$, for a distribution with two parameters)

Cerne, Lavras, v. 18, n. 2, p. 185-196, abr./jun. 2012 


\subsection{Function fitting and assessment}

Dbh data from each plot and measurement occasion were grouped into class intervals of $1.0 \mathrm{~cm}$. Functions were fitted using the maximum likelihood method, with software kyplot Version 2.0 beta 15 (1997-2001c Koichi Yoshioka). Functions having a location parameter were fitted with and without the parameter, as it can be replaced by the minimum diameter of the stand (CLUTTER et al., 1983). The following functions were thus fitted: Log-logistic (3P), Log-logistic (2P), Burr (4P), Burr (3P), Hyperbolic (3P), Hyperbolic (2P), Weibull (3P), Weibull (2P), Fatigue Life (3P), Fatigue Life (2P) Nakagami, Gamma (3P), Gamma (2P), Generalized Gamma (4P), Generalized Gamma (3P), Generalized Logistic, Logistic, Frechet (3P), Frechet (2P), Beta, Dagum (4P), Dagum (3P), and numbers in brackets refer to the amount of parameters being used.

In order to test the goodness-of-fit of a function to data, the Kolmogorov-Smirnov test was used (GIBBONS; SUBHABRATA, 1992; SOKAL; ROHLF, 1981). This test compares estimated cumulative frequency with observed frequency, the maximum difference being the test statistic $(d n)$. All fittings were compared through graphical analysis of observed and estimated values and mean values of the $\mathrm{K}-\mathrm{S}$ test.

Considering that these functions are used in diameter distribution models and considering, in this case, the need to obtain a significant correlation of their parameters with the characteristics of the stands (LEITE, 1990) a correlation matrix was estimated between the parameters and the variables: maximum diameter, minimum diameter, quadratic diameter, age, number of trees, also correlating parameter values at age $i$ with an earlier age $i-1$.

\section{RESULTS AND DISCUSSION}

Functions were fitted to each plot and measurement occasion, to a total of 2,856 fittings per function. Graphical analyses between estimated and observed values for three measurement occasions of a randomly selected plot are provided in Figure 1. Function fit assessment was based on K-S test values, the function providing the lowest mean values being considered the best function. Results of the $\mathrm{K}-\mathrm{S}$ test for function fitting are provided in Table 1. Table 2 illustrates correlations between stand characteristics and functions parameters.

The diameter distribution modeling in stands of Tectona grandis L. f. (teak) has been performed based on the prediction and/or projection of parameters of a statistical distribution, using regression models. The twoparameter Weibull function has been used in the majority of related studies on account of its flexibility and easy correlation of its parameters with stand characteristics (NOGUEIRA et al., 2005).

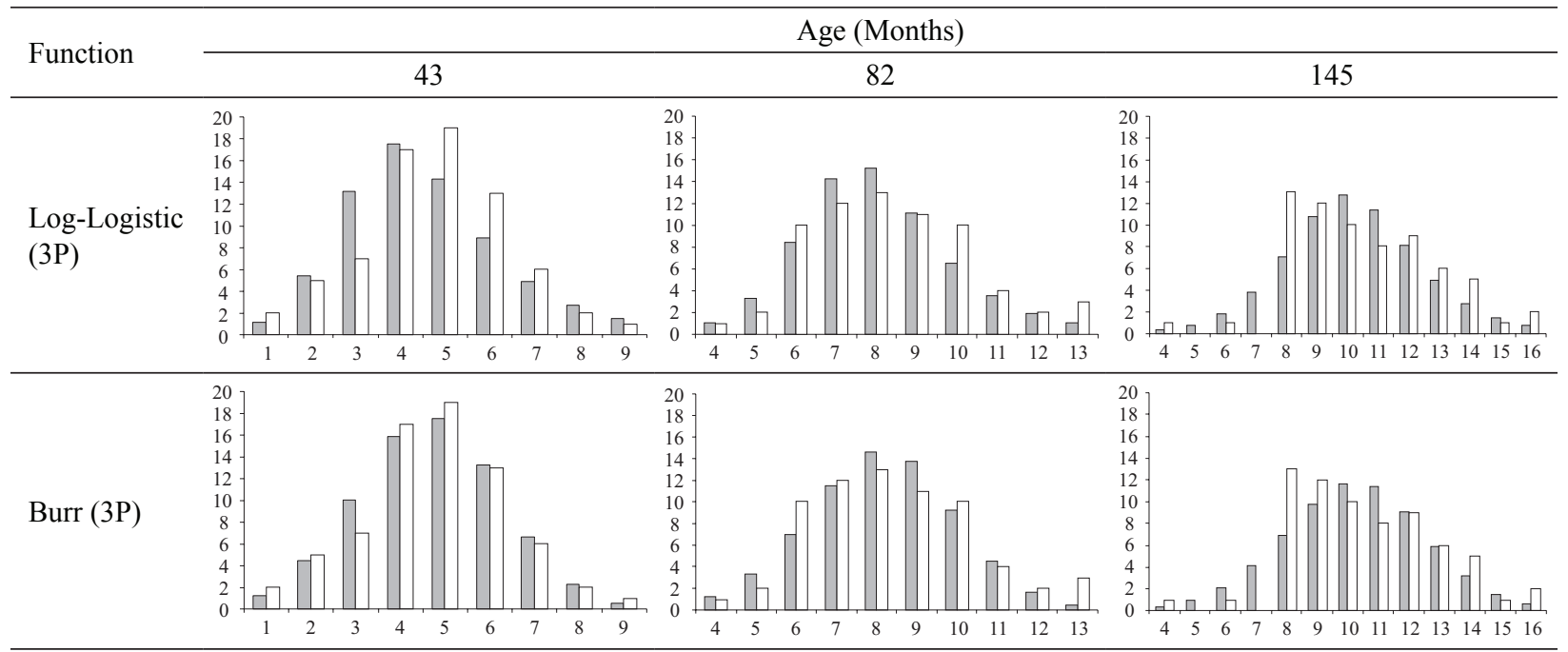

Figure 1 - Observed values (in white) and estimated values (in gray) according to each tested function, for one plot in three measurement occasions.

Figura 1 - Valores observados (branco) e estimado (cinza), por todas as funções testadas para uma parcela em três medições.

To be continued... Continua...

Cerne, Lavras, v. 18, n. 2, p. 185-196, abr./jun. 2012 


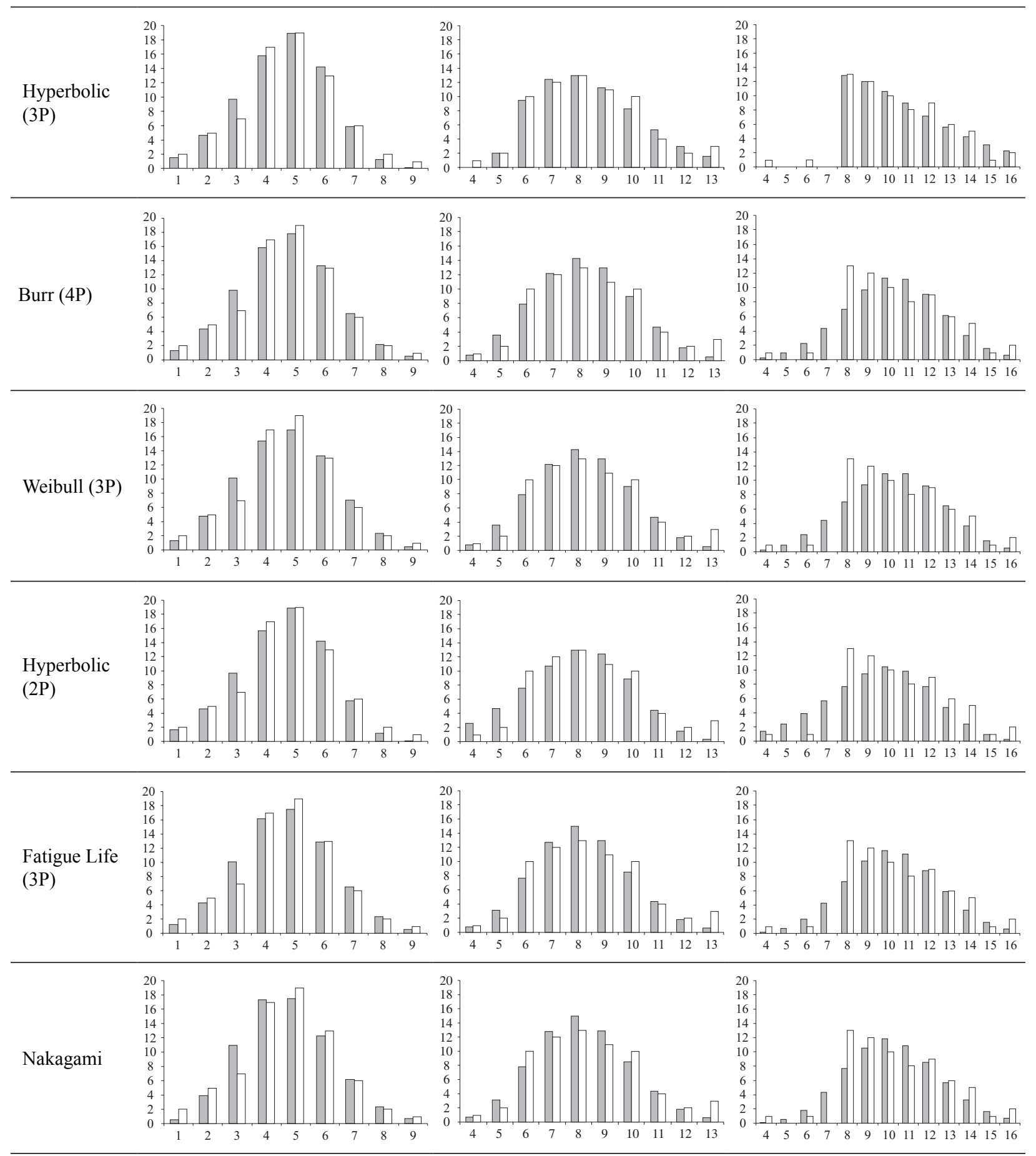

Figure 1 - Continued...

Figura 1 - Continuação...

To be continued...

Continua..

Cerne, Lavras, v. 18, n. 2, p. 185-196, abr./jun. 2012 


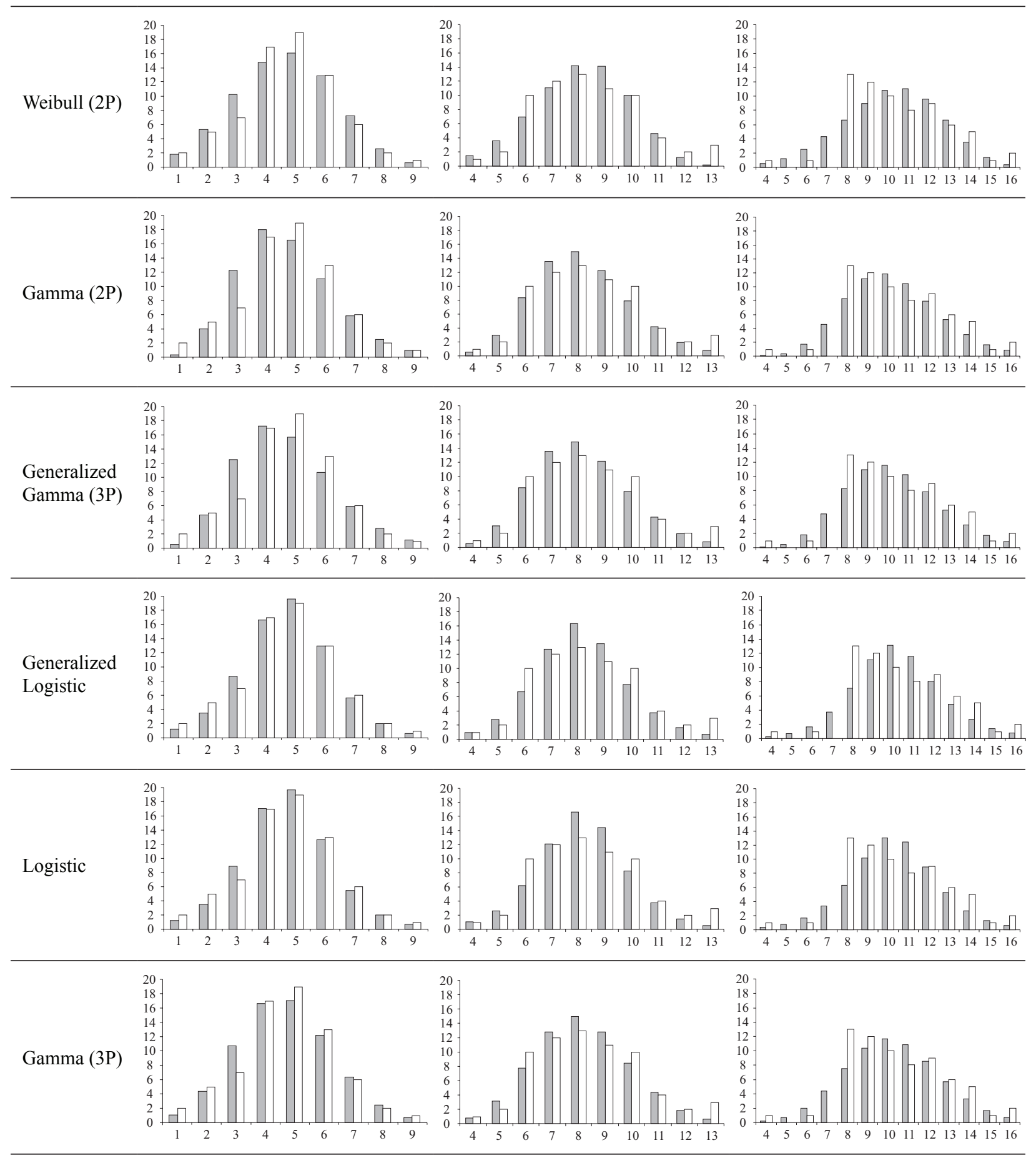

Figure 1 - Continued...

Figura 1 - Continuação...

To be continued...

Continua..

Cerne, Lavras, v. 18, n. 2, p. 185-196, abr./jun. 2012 


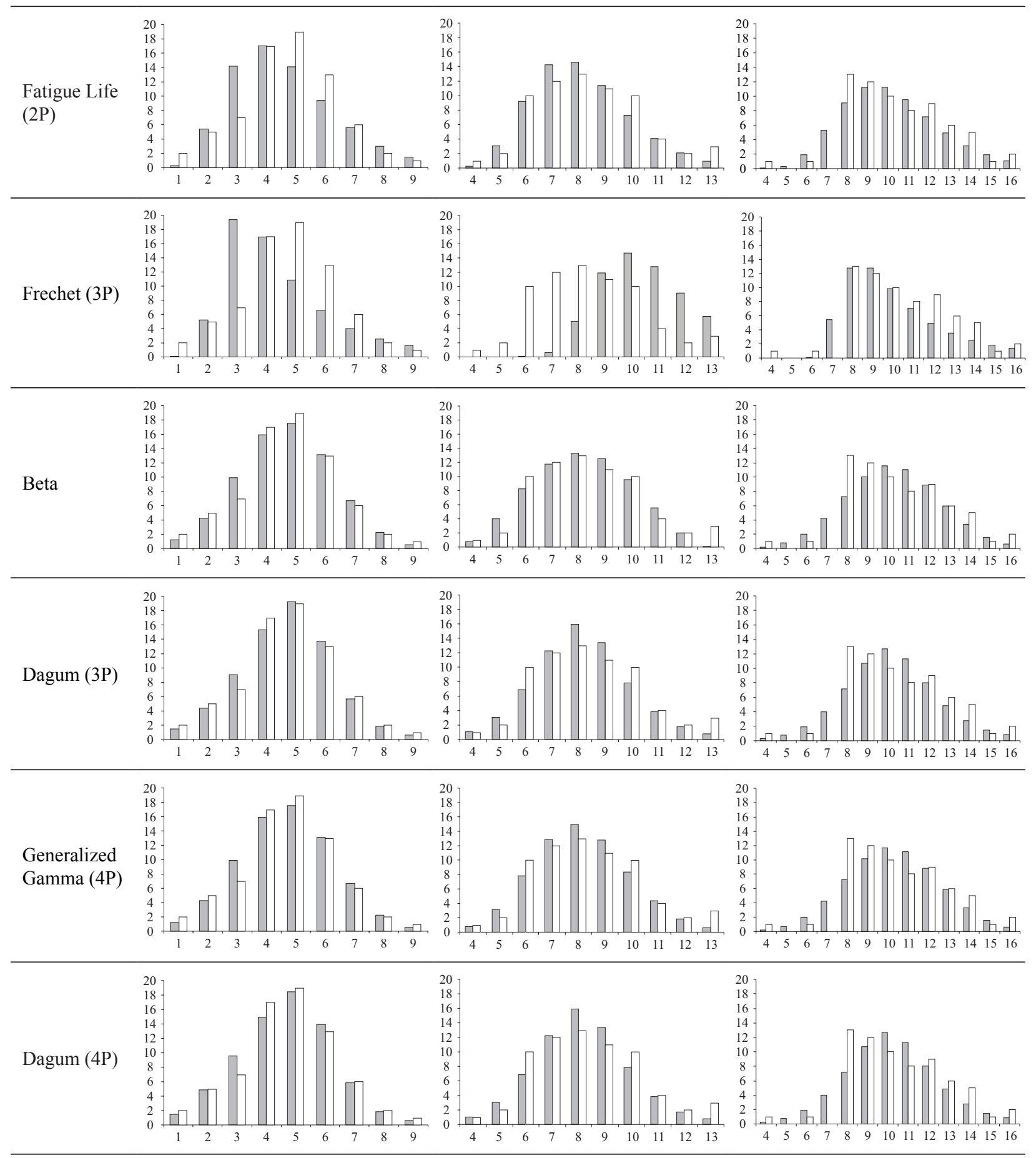

Figure 1 - Continued...

Figura 1 - Continuação...

To be continued... Continua...

Cerne, Lavras, v. 18, n. 2, p. 185-196, abr./jun. 2012 

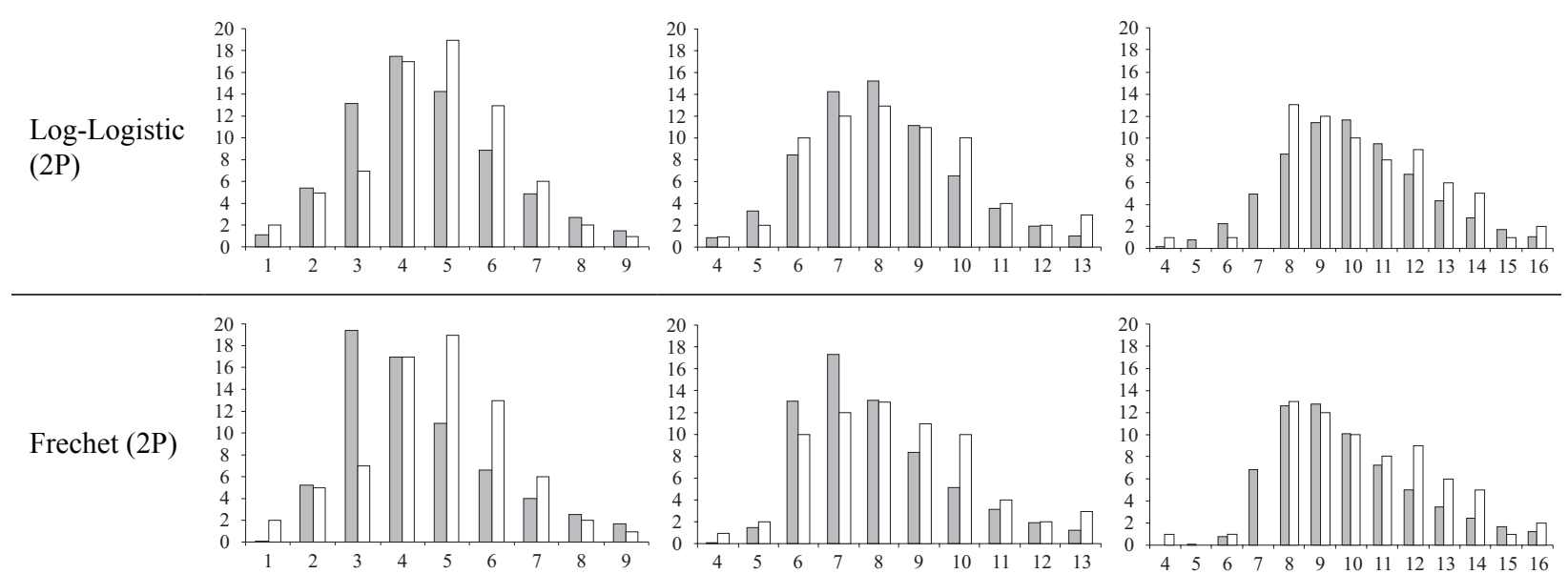

Figure 1 - Continued.

Figura 1 - Continuação.

Table 1 - Mean values of the Kolmogorov-Smirnov test for the tested functions. Numbers in brackets refer to the amount of parameters being used.

Tabela 1 - Média dos valores do teste Kolmogorov-Smirnov das funções testadas, para todos os ajustes. O valor entre parênteses refere-se ao número de parâmetros utilizado no ajuste.

\begin{tabular}{lcllc}
\hline p.d.f. & Mean (K-S) & & p.d.f. & Mean (K-S) \\
\cline { 1 - 2 } Log-logistic (3P) & 0.1680 & Generalized Logistic & 0.1877 \\
Burr (3P) & 0.1690 & & Logistic & 0.1887 \\
Hyperbolic (3P) & 0.1700 & & Gamma (3P) & 0.1887 \\
Burr (4P) & 0.1709 & & Fatigue Life (2P) & 0.1962 \\
Weibull (3P) & 0.1710 & Frechet (3P) & 0.2014 \\
Hyperbolic (2P) & 0.1722 & Beta & 0.2014 \\
Fatigue Life (3P) & 0.1737 & Dagum (3P) & 0.2020 \\
Nakagami & 0.1794 & Generalized Gamma (4P) & 0.2139 \\
Weibull (2P) & 0.1800 & & Dagum (4P) & 0.2678 \\
Gamma (2P) & 0.1855 & Log-logistic (2P) & 0.3286 \\
Generalized Gamma (3P) & 0.1868 & Frechet (2P) & 0.3993 \\
\hline
\end{tabular}

Table 2 - Correlation between stand characteristics and function parameters.

Tabela 2 - Correlação entre características do povoamento e os parâmetros das funções ajustadas.

\begin{tabular}{lccccccc}
\hline \multirow{2}{*}{ Function } & Parameter & $\begin{array}{c}\text { Minimum } \\
\mathrm{dbh}\end{array}$ & $\begin{array}{c}\text { Maximum } \\
\mathrm{dbh}\end{array}$ & $\begin{array}{c}\text { Number of } \\
\text { trees }\end{array}$ & $\begin{array}{c}\text { Quadratic } \\
\text { Diameter }\end{array}$ & $\begin{array}{c}\text { Age } \\
\text { Parameter at } \\
\text { I(i-1) }\end{array}$ \\
\hline \multirow{2}{*}{ Weibull (2P) } & $\beta$ & 0.803 & 0.649 & -0.451 & 0.717 & 0.512 & 0.698 \\
& $\gamma$ & 0.967 & 0.990 & -0.592 & 1.000 & 0.724 & 0.892 \\
\hline
\end{tabular}

To be continued..

Continua..

Cerne, Lavras, v. 18, n. 2, p. 185-196, abr./jun. 2012 
Table 2 - Continued...

Tabela 2 - Continuação...

\begin{tabular}{|c|c|c|c|c|c|c|c|}
\hline Function & Parameter & $\begin{array}{c}\text { Minimum } \\
\mathrm{dbh}\end{array}$ & $\begin{array}{l}\text { Maximum } \\
\mathrm{dbh}\end{array}$ & $\begin{array}{c}\text { Number of } \\
\text { trees }\end{array}$ & $\begin{array}{l}\text { Quadratic } \\
\text { Diameter }\end{array}$ & Age & $\begin{array}{c}\text { Parameter at } \\
\text { I(i-1) }\end{array}$ \\
\hline \multirow{3}{*}{ Weibull (3P) } & $\beta$ & -0.174 & -0.110 & 0.091 & -0.094 & -0.106 & 0.353 \\
\hline & $\gamma$ & -0.163 & -0.095 & 0.086 & -0.081 & -0.093 & 0.313 \\
\hline & $\alpha$ & 0.163 & 0.095 & -0.086 & 0.081 & 0.093 & 0.313 \\
\hline \multirow{2}{*}{ Fatigue Life (2P) } & $\beta$ & -0.756 & -0.638 & 0.404 & -0.689 & -0.486 & 0.625 \\
\hline & $\gamma$ & 0.975 & 0.987 & -0.599 & 1.000 & 0.725 & 0.899 \\
\hline \multirow{3}{*}{ Fatigue Life (3P) } & $\beta$ & -0.081 & -0.114 & -0.065 & -0.108 & -0.091 & -0.003 \\
\hline & $\gamma$ & -0.490 & -0.367 & 0.454 & -0.362 & -0.586 & 0.526 \\
\hline & $\alpha$ & 0.493 & 0.369 & -0.450 & 0.364 & 0.581 & 0.523 \\
\hline \multirow{2}{*}{ Frechet (2P) } & $\beta$ & 0.830 & 0.674 & -0.485 & 0.733 & 0.547 & 0.699 \\
\hline & $\gamma$ & 0.981 & 0.982 & -0.600 & 0.998 & 0.724 & 0.904 \\
\hline \multirow{3}{*}{ Frechet (3P) } & $\beta$ & -0.123 & -0.118 & 0.122 & -0.102 & -0.133 & 0.222 \\
\hline & $\gamma$ & -0.217 & -0.163 & 0.231 & -0.158 & -0.261 & 0.209 \\
\hline & $\alpha$ & 0.370 & 0.314 & -0.416 & 0.323 & 0.519 & 0.381 \\
\hline \multirow{2}{*}{ Gamma (2P) } & $\beta$ & 0.740 & 0.582 & -0.461 & 0.663 & 0.485 & 0.755 \\
\hline & $\gamma$ & -0.291 & -0.084 & 0.085 & -0.178 & -0.020 & 0.552 \\
\hline \multirow{3}{*}{ Gamma (3P) } & $\beta$ & -0.474 & -0.375 & 0.433 & -0.343 & -0.466 & 0.574 \\
\hline & $\gamma$ & 0.187 & 0.199 & -0.262 & 0.231 & 0.456 & 0.533 \\
\hline & $\alpha$ & 0.242 & 0.239 & -0.302 & 0.269 & 0.501 & 0.540 \\
\hline \multirow{3}{*}{$\begin{array}{l}\text { Generalized } \\
\text { Logistic }\end{array}$} & $\beta$ & 0.462 & 0.401 & -0.386 & 0.357 & 0.410 & 0.675 \\
\hline & $\gamma$ & 0.575 & 0.756 & -0.386 & 0.688 & 0.580 & 0.663 \\
\hline & $\alpha$ & 0.969 & 0.986 & -0.593 & 1.000 & 0.722 & 0.896 \\
\hline \multirow{2}{*}{ Log-Logistic (2P) } & $\beta$ & 0.815 & 0.660 & -0.462 & 0.724 & 0.525 & 0.697 \\
\hline & $\gamma$ & 0.974 & 0.987 & -0.596 & 1.000 & 0.723 & 0.899 \\
\hline \multirow{3}{*}{ Log-Logistic (3P) } & $\beta$ & -0.343 & -0.271 & 0.261 & -0.254 & -0.328 & 0.339 \\
\hline & $\gamma$ & -0.303 & -0.216 & 0.228 & -0.205 & -0.269 & 0.275 \\
\hline & $\alpha$ & 0.333 & 0.261 & -0.357 & 0.273 & 0.479 & 0.339 \\
\hline \multirow{2}{*}{ Nakagami } & $\beta$ & -0.210 & -0.223 & 0.016 & -0.216 & -0.082 & 0.428 \\
\hline & $\gamma$ & 0.958 & 0.967 & -0.616 & 0.978 & 0.708 & 0.966 \\
\hline \multirow{4}{*}{ Beta } & $\alpha 1$ & -0.199 & -0.115 & 0.151 & -0.118 & -0.205 & 0.070 \\
\hline & $\alpha 2$ & 0.013 & 0.028 & 0.004 & 0.016 & 0.036 & 0.000 \\
\hline & $a$ & 0.226 & 0.131 & -0.181 & 0.131 & 0.226 & 0.104 \\
\hline & $b$ & 0.012 & 0.028 & 0.005 & 0.015 & 0.036 & 0.000 \\
\hline \multirow{2}{*}{ Logistic } & $\sigma$ & 0.537 & 0.742 & -0.363 & 0.668 & 0.547 & 0.629 \\
\hline & $\mu$ & 0.972 & 0.988 & -0.598 & 1.000 & 0.726 & 0.897 \\
\hline
\end{tabular}

To be continued... Continua...

Cerne, Lavras, v. 18, n. 2, p. 185-196, abr./jun. 2012 
Table 2 - Continued...

Tabela 2 - Continuação...

\begin{tabular}{|c|c|c|c|c|c|c|c|}
\hline Function & Parameter & $\begin{array}{c}\text { Minimum } \\
\mathrm{dbh}\end{array}$ & $\begin{array}{c}\text { Maximum } \\
\mathrm{dbh}\end{array}$ & $\begin{array}{c}\text { Number of } \\
\text { trees }\end{array}$ & $\begin{array}{l}\text { Quadratic } \\
\text { Diameter }\end{array}$ & Age & $\begin{array}{c}\text { Parameter at } \\
\text { I(i-1) }\end{array}$ \\
\hline \multirow{3}{*}{ Dagum (3P) } & $k$ & 0.476 & 0.436 & -0.396 & 0.438 & 0.378 & 0.404 \\
\hline & $\alpha$ & 0.013 & -0.003 & -0.055 & 0.019 & 0.020 & 0.015 \\
\hline & $\beta$ & 0.733 & 0.786 & -0.402 & 0.801 & 0.536 & 0.631 \\
\hline \multirow{4}{*}{ Dagum (4P) } & $k$ & 0.282 & 0.296 & -0.205 & 0.301 & 0.258 & 0.147 \\
\hline & $\alpha$ & -0.132 & -0.113 & 0.121 & -0.108 & -0.144 & 0.094 \\
\hline & $\beta$ & -0.111 & -0.082 & 0.101 & -0.082 & -0.112 & 0.094 \\
\hline & $\gamma$ & 0.111 & 0.082 & -0.101 & 0.082 & 0.112 & 0.094 \\
\hline \multirow{3}{*}{ Burr (3P) } & $k$ & -0.390 & -0.342 & 0.200 & -0.319 & -0.259 & 0.470 \\
\hline & $\alpha$ & 0.109 & 0.082 & -0.119 & 0.084 & 0.083 & 0.050 \\
\hline & $\beta$ & 0.338 & 0.419 & -0.237 & 0.437 & 0.323 & 0.469 \\
\hline \multirow{4}{*}{ Burr (4P) } & $k$ & -0.033 & -0.053 & -0.062 & -0.046 & 0.000 & -0.001 \\
\hline & $\alpha$ & 0.095 & 0.119 & -0.048 & 0.109 & 0.040 & 0.115 \\
\hline & $\beta$ & -0.033 & -0.053 & -0.062 & -0.046 & 0.000 & -0.001 \\
\hline & $\gamma$ & -0.087 & -0.122 & 0.042 & -0.107 & -0.036 & 0.057 \\
\hline \multirow{3}{*}{$\begin{array}{l}\text { Generalized } \\
\text { Gamma (3P) }\end{array}$} & $k$ & 0.603 & 0.471 & -0.491 & 0.467 & 0.508 & 0.065 \\
\hline & $\alpha$ & 0.756 & 0.595 & -0.479 & 0.674 & 0.504 & 0.751 \\
\hline & $\beta$ & -0.291 & -0.084 & 0.085 & -0.178 & -0.020 & 0.552 \\
\hline \multirow{4}{*}{$\begin{array}{l}\text { Generalized } \\
\text { Gamma (4P) }\end{array}$} & $k$ & -0.118 & -0.086 & 0.086 & -0.084 & -0.114 & 0.007 \\
\hline & $\alpha$ & -0.183 & -0.141 & 0.208 & -0.110 & -0.229 & 0.270 \\
\hline & $\beta$ & -0.118 & -0.081 & 0.088 & -0.081 & -0.114 & 0.010 \\
\hline & $\gamma$ & 0.118 & 0.081 & -0.088 & 0.081 & 0.114 & 0.010 \\
\hline \multirow{2}{*}{ Hyperbolic (2P) } & $\beta$ & 0.932 & 0.959 & -0.563 & 0.969 & 0.705 & 0.858 \\
\hline & $\alpha$ & 0.212 & 0.178 & -0.120 & 0.204 & 0.136 & 0.324 \\
\hline \multirow{3}{*}{ Hyperbolic (3P) } & $\gamma$ & 0.667 & 0.613 & -0.428 & 0.645 & 0.476 & 0.524 \\
\hline & $\beta$ & 0.304 & 0.395 & -0.168 & 0.370 & 0.267 & 0.339 \\
\hline & $\alpha$ & 0.103 & 0.148 & -0.031 & 0.143 & 0.060 & 0.245 \\
\hline
\end{tabular}

The effectiveness of estimates generated by diameter distribution models is conditional not only on data quality and equation fitting quality but also on correlation capability between pdf parameters and easily measurable stand characteristics (LEITE, 1990).

This study evaluated the application of functions with differing characteristics to describe the diameter structure of teak stands subjected to thinning. The LogLogistic (3P), Burr (3P), Hyperbolic (3P), Burr (4P), Weibull (3P), Hyperbolic (2P), Fatigue Life (3P) and Nakagami functions provided more satisfactory values for the k-s test than the more commonly used Weibull function.
Nevertheless, all functions being analyzed in this study provided satisfactory results for use in growth and yield modeling of thinned teak stands.

The linear correlations between stand characteristics and function parameters revealed that inclusion of a location parameter may obstruct the construction of diameter distribution models. The Weibull (2P), Fatigue Life (2P), Frechet (2P), Generalized Logistic, Log-Logistic (2P), Logistic, Hyperbolic (2P) functions provided satisfactory linear correlations between parameters and stand characteristics, yet nonlinear correlations can be found and used in construction of diameter distribution models.

Cerne, Lavras, v. 18, n. 2, p. 185-196, abr./jun. 2012 
Among the tested functions, the hyperbolic function, as proposed by Guimarães (2002) and used in this study, has great potential to describe diameter distribution of forest stands on account of its flexibility. The inflection point of this function ranges from zero to the upper limit defined by $I=\tanh (1)=0.76$. This confers greater flexibility in comparison with the Weibull function, whose inflection points range between zero and the limit of $\mathrm{I}=(1-1 / \mathrm{e})=0.63$. Thus, the characteristic given by many authors to justify using the Weibull function to describe diameter structure in thinned stands is even more substantial in the case of the hyperbolic function. In addition, the parameters of this function are easily correlated with stand characteristics, as was observed by Campos e Leite (2009) and Leite et al. (2010).

Functions were fitted using the maximum likelihood method only. Other fitting methods should be tested that include percentiles method (GUIMARÃES, 1994), methods of moments (FRAZIER, 1981) and moments-1 in order to determine how best to use each function.

\section{CONCLUSION}

This study demonstrated that, other than the Weibull function, other functions can be used to describe the diameter structure of stands subjected to thinning, potentially resulting in greater accuracy than the more commonly used Weibull function, noting that they should also be tested with other types of stand.

\section{REFERENCES}

ABBASI, B.; JAHROMIA, A. H. E.; ARKAT, J.; HOSSEINKOUCHACK, M. Estimating the parameters of Weibull distribution using simulated annealing algorithm. Applied Mathematics and Computation, New York, v. 183, n. 1, p. 85-93, Mar. 2006.

ABBASI, B.; RABELO, L.; HOSSEINKOUCHACK, M. Estimating parameters of the three-parameter Weibull distribution using a neural network. European Journal of Industrial Engineering, Oxford, v. 2, n. 4, p. 428-445, 2008.

BAILEY, R. L.; BURGAN, T. M.; JOKELA, E. J. Fertilized midrotation-aged slash pine plantations: stand structure and yield prediction models. Southern Journal of Applied Forestry, Washington, v. 13, n. 2, p. 76-80, 1989.
BAILEY, R. L.; DELL, T. R. Quantifying diameter distributions with the Weibull function. Forest Science, Bethesda, v. 19, n. 2, p. 97-104, 1973.

BALDWIN JUNIOR, V. C.; FEDUCCIA, D. P. Loblolly pine growth and yield prediction of managed West Gulf plantations. New Orleans: USDA, 1987. 27 p.

BLISS, C. L.; REINKER, K. A. A lognormal approach to diameter distributions in even-aged stands. Forest Science, Bethesda, v. 10, p. 350-360, 1964.

BURY, K. Statistical distributions in engineering. Cambridge: Cambridge University, 1998. 362 p.

CAMPOS, J. C. C.; LEITE, H. G. Mensuração florestal: perguntas e respostas. 3. ed. Viçosa, MG: UFV, 2009. 548 p.

CAMPOS, J. C. C.; TURNBULL, K. Um sistema para estimar a produção por classe de diâmetro e sua aplicação na interpretação do efeito de desbaste. Revista Árvore, Viçosa, v. 5, n. 1, p. 1-16, 1981.

CAO, Q. V. Predicting parameters of a Weibull function for modeling diameter distribution. Forest Science, Oxford, v. 50, n. 4, p. 682-685, 2004.

CLUTTER, J. L.; ALLISON, B. J. A growth and yield model for Pinus radiata in New Zealand for tree and stand simulation. Royal College of Forestry, London, n. 30, p. 136-160, 1974.

CLUTTER, J. L.; BENNETT, F. A. Diameter distributions in old: field slash pine plantations. Georgia Forest Research Council Report, Maple, n. 13, p. 1-9, 1965.

CLUTTER, J. L.; FORTSON, J. C.; PIENAAR, L. V.; BRISTER, R. G. H.; BAILEY, R. L. Timber management: a quantitative approach. New York: J. Willey, 1983. 333 p.

FISHER, R. A. On the mathematical foundations of theoretical statistics. Philosophical Transactions of the Royal Society of London, Serie A, London, v. 222, p. 309368, 1922.

FRAZIER, J. R. Compatible whole-stand and diameter distribuition models for loblolly pine plantations. 1981. 125 f. Dissertation (Master) - Virginia Polytech Institute and State University, Blackburg, 1981.

Cerne, Lavras, v. 18, n. 2, p. 185-196, abr./jun. 2012 
GIBBONS, J. D.; SUBHABRATA, C. Nonparametric statistical inference. 3. ed. New York: M. Dekker, 1992. 544 p.

GUIMARÃES, D. P. Desenvolvimento de um modelo de distribuição diamétrica de passo invariante para prognose e projeção da estrutura de povoamentos de eucalipto. 1994. Tese (Doutorado em Ciência Florestal) - Universidade Federal de Viçosa, Viçosa, 1994.

GUIMARÃES, D. P. Uma função hiperbólica de distribuição probabilística de alta flexibilidade. Planaltina: Embrapa Cerrados, 2002. 40 p.

HAFLEY, W. L.; SCHREUDER, H. T. Statistical distributions for fitting diameter and height data in ever-aged stands.

Canadian Journal of Forest Research, Ottawa, v. 7, p. 184487, 1977.

JOHNSON, N. L.; KOTZ, S.; BALAKRISHNAN, N. Continuous univariate distributions. New York: Applied Probability and Statistics, 1995. 732 p.

KLEIBER, C.; KOTZ, S. Statistical size distributions in economics and actuarial sciences. New York: J. Wiley, 2003. $353 \mathrm{p}$.

KNOEBELL, B. R.; BURKHART, H. E.; BECK, D. E. A growth and yield model for thinned stands of yellow-poplar. Forest Science, Oxford, v. 32, n. 2, p. 62, 1986.

KNOWE, S. A.; AHRENS, G. A.; DEBELL, D. S. Comparison of diameter-distribution -prediction, stand-table -projection and individual-tree growth modeling approaches for young red alder plantations. Forest Ecology and Management, Amsterdam, v. 96, p. 207-216, 1997.

\section{KRISHNAMOORTHY, K. Handbook of statistical} distributions with applications. London: Taylor \& Francis, 2006. 346 p. (Statistics, a series of textbooks \& monographs, 188).

LAURENSON, D. Nakagami distribution: indoor radio channel propagation modelling by ray tracing techniques. [S.1.: s.n.], 1994.
LEITE, H. G. Ajuste de um modelo de estimação de freqüência e produção por classe de diâmetro, para povoamentos de Eucalyptus saligna Smith. 1990. $81 \mathrm{f}$. Dissertação (Mestrado em Ciência Florestal) - Universidade Federal de Viçosa, Viçosa, 1990.

LEITE, H. G.; BINOTI, D. H. B.; GUIMARÃES, D. P.; SILVA, M. L. M.; GARCIA, S. L. R. Avaliação do ajuste das funções Weibull e hiperbólica a dados de povoamentos de eucalipto submetidos a desbaste. Revista Árvore, Viçosa, v. 34, n. 2, p. 220-226, 2010.

LEITE, H. G.; NOGUEIRA, G. S.; CAMPOS, J. C. C.; TAKIZAWA, F. H.; RODRIGUES, F. L. Um modelo de distribuição diamétrica para povoamentos de Tectona grandis submetidos a desbaste. Revista Árvore, Viçosa, v. 30, n. 1, p. 89-98, 2006.

MATNEY, T. G.; SULLIVAN, A. D. Variable top volume and height predictions for slash pine trees. Forest Science, Bethesda, v. 28, n. 2, p. 74-82, 1982.

MURTHY, D. N. P.; XIE, M.; JIANG, R. Weibull models. New York: Wiley, 2004. 396 p.

NELSON, T. C. Diameter distribution and growth of loblolly pine. Forest Science, Bethesda, v. 10, n. 1, p. 105-114, 1964.

NOGUEIRA, G. S.; LEITE, H. G.; CAMPOS, J. C. C.; CARVALHO, A. F.; SOUZA, A. L. de. Modelo de distribuição diamétrica para povoamentos de Eucalyptus sp. submetidos a desbaste. Revista Árvore, Viçosa, v. 29, n. 4, p. 579-589, jul./ ago. 2005.

SIIPILEHTO, J.; SARKKOLA, S.; MEHTÄTALO, L. Comparing regression estimation techniques when predicting diameter distributions of Scots pine on drained peatlands. Silva Fennica, Helsinski, v. 41, n. 2, p. 333-349, 2007.

SOKAL, R. R.; ROHLF, F. J. Biometry. San Francisco: Freeman, 1981.859 p.

WEIBULL, W. A statistical distribution function of wide applicability. Journal of Applied Mechanics, New York, v. 18, p. 293-297, 1951. 